Turkish Online Journal of Qualitative Inquiry (TOJQI)

Volume 12, Issue 1, January 2021: 1-23

DOI: $10.17569 /$ tojqi.788363

Research Article

\title{
Comparison of Pre-Service Teachers' Teaching Experiences in Virtual Classroom and Face-to-Face Teaching Environment ${ }^{1}$
}

\author{
Şerife $\mathrm{Ak}^{2}$, İbrahim Gökdaş ${ }^{3}$
}

\begin{abstract}
The study was carried out with the aim of evaluating the pre-service teachers' teaching experiences in virtual classroom and face-to-face teaching environment. Complementarity mixed research method was used in the study. The study group was composed of 40 pre-service teachers. Quantitative data was collected through the online teaching experience questionnaire I and II form, immediately after the pre-service teachers experienced the teaching process in two different teaching environments. Following this, semi-structured interviews were conducted with all the pre-service teachers to obtain detailed information regarding their teaching experiences. In the analysis of quantitative data, descriptive statistics and Wilcoxon Signed Rank test was used to compare the perceived anxiety, motivation, performance and efficiency levels of the preservice teachers while performing the teaching role in virtual classroom and face-to-face teaching environment. In the analysis of qualitative data, descriptive content analyses were used. As a result of the study, it was determined that the majority of the pre-service teachers preferred face-to-face teaching environment for such reasons as teacher-student interaction and eye contact. While there was not a significant difference in terms of the anxiety levels perceived by the pre-service teachers during performing the teaching role in virtual classroom and face-to-face teaching environment, it was determined that there was a significant difference in terms of the perceived motivation, perceived performance and perceived efficiency on behalf of face-to-face teaching experience. Limitations and implications of the findings are discussed, and future directions are provided.
\end{abstract}

Keywords: Pre-service teacher, teaching experience, virtual classroom

\footnotetext{
${ }^{1}$ The ethical committee permission is not required in this study since the data were gathered before 2020 .

${ }^{2}$ Assoc.Prof.Dr., Aydın Adnan Menderes University, Faculty of Education, Department of Computer Education and Instructional Technologies, serife.ak@adu.edu.tr, ORCID ID: 0000-0002-7148-620X.

${ }^{3}$ Assoc.Prof.Dr., Aydin Adnan Menderes University, Faculty of Education, Department of Computer Education and Instructional Technologies, ibrahimgokdas@adu.edu.tr, ORCID ID: 0000-0001-7019-8735.
}

Received: 31.08.2020, Accepted: 11.01.2021 


\title{
Öğretmen Adaylarının Sanal Sınıf ve Yüz Yüze Öğretim Ortamındaki Öğretme Deneyimlerinin Karşılaştırılması
}

\begin{abstract}
$\ddot{\mathbf{O} z}$
Çalışma öğretmen adaylarının sanal sınıf ve yüz yüze öğretme ortamında yaşadıkları öğreticilik deneyimlerinin değerlendirilmesi amacıyla gerçekleştirilmiştir. Çalışmada tamamlayıcı karma araştırma yöntemi kullanılmıştır. Çalışma grubu Bilgisayar ve Öğretim teknolojileri Eğitimi Bölümü 3. sınıfında okuyan ve Özel Öğretim Yöntemleri I ve II derslerini alan 40 öğretmen adayından oluşmaktadır. Çalışmaya katılan öğretmen adaylarının yaşları 21-27 arasında değişmektedir. Öğretmen adaylarının 12'si kadın, 28'i erkektir. Görüşmeler öğretmen adaylarının tamamı ile gerçekleştirilmiştir. Öğretmen adaylarının öğretim sürecini iki farklı öğretim ortamında deneyimlemesinin hemen ardından, çevrimiçi öğretim deneyimi anketi I ve II formu aracıllğıyla nicel veriler toplanmıştır. Bunu takiben öğretmen adaylarının öğretmenlik deneyimleri hakkında detaylı bilgi almak için tüm öğretmen adaylarıyla yarı yapılandırılmış görüşmeler yapılmıştır. Nicel verilerin analizinde betimsel istatistikler ve öğrencilerin sanal sınıf ve yüzü yüze öğretme ortamında öğretici rolünü gerçekleştirirken algıladıkları kaygı, motivasyon, performans ve verimlilik düzeylerinin karşılaştırılmasında Wilcoxon İşaretli sıralar testi kullanılmıştır. Nitel verilerin analizinde ise betimsel analizlerden yararlanılmıştır. Çalışma sonunda öğretmen adaylarının büyük çoğunluğunun öğretmen-öğrenci etkileşimi ve göz teması kurma gibi nedenlerle yüz yüze öğretme ortamını tercih ettiği belirlenmiştir. Öğretmen adaylarının sanal sınıf ve yüzü yüze öğretme ortamında öğretici rolünü gerçekleştirirken algıladıkları kaygı düzeyleri açısından anlamlı fark görülmezken; algılanan motivasyon, algılanan performans ve algılanan verimlilik açısından yüz yüze öğretme ortamındaki öğretme deneyimi lehine anlamlı bir fark olduğu belirlenmiştir. Sonuçlar ilgili literatür çerçevesinde tartışılmış ve önerilerde bulunulmuştur.
\end{abstract}

Anahtar kelimeler: Öğretmen adayl, ögretme deneyimi, sanal sinıf. 


\section{Introduction}

In addition to the rapid change in technology, the emergence of urgent and compulsory distance education experience because coronavirus pandemic has revealed the importance of the design of online teaching-learning environments. In terms of the quality of digital learning and teaching environments, the quality of the teacher who will be teaching and his/her knowledge, skills and experience of e-learning are of great importance (Baker, 2004; Cab1, 2018; Kairu, 2020; Sae-Khow, 2014; Shea, Li and Pickett, 2006; Yılmazsoy, Özdinç \& Kahraman, 2018). Shea et al. (2006) indicated that active and strong presence of teachers in online teaching is even more critical for students' sense of learning than the design of online teaching environments. However, the majority of teachers do not feel that they are equipped enough with regard to teaching via online platforms (He, 2014; Sprague, Kopfman \& Dorsey, 1998) and they have some negative emotional responses to teaching online such as feeling stressed or restricted through perceptions of teaching performance as an online teacher (Badia, Garcia, \& Meneses, 2017; Badia, Garcia, \& Meneses, 2019; Naylor \& Nyanjom, 2020; Regan et al., 2012).

It is known that emotions effects teachers' perceptions, beliefs and motivation as a critical factor (Chen, 2019; Naylor \& Nyanjom, 2020). Therefore, an increased understanding of teachers' emotional responses to teaching online is essential for prepare them to use of online teaching-learning environments effectively (Badia et al, 2017). Trigwell (2012) classified emotions involved in teaching into positive and negative forms of motivation, anxiety, pride, embarrassment and frustration. Badia, Meneses and Monereo (2014) identified a three categories of emotions involved in teaching included teaching motivation, self -evaluation of oneself as a teacher and teaching efficiency. Badia et al. (2019) demonstrated the importance of teachers' relationship with technology on their emotional responses teaching online such as feeling relaxed or stressed.

Teachers should be provided online teaching and interaction opportunities before and after graduation (Anderson, Standerford \& Imdieke, 2010) in order to being skilled using technology and pedagogy in both online and face to face teaching and being manage the negative emotional responses to teaching. Besides, being skilled using technology and pedagogy can be used by 
teachers as a managing strategy of the negative emotions (Bennett, 2014). According to Ertmer and Ottenbreit-Leftwich (2010), teachers' professional trainings primarily should focused on enhancing teachers' knowledge and skills about using technology in order to help reduce the fear associated with online teaching. For this reason, all pre-service teachers should be given the opportunity to experience online learning during their undergraduate education process (Compton, David \& Mackey, 2009; Kennedy \& Archambault, 2012; He, 2014; Downing \& Dyment, 2013). The findings of the study conducted by Yildiz (2011) revealed that the preservice teachers who had the opportunity to experience online synchronous course developed a positive attitude towards distance education. A qualitative research was carried out by Cab1 (2018) with 12 instructors in order to examine the experiences of the instructors during the distance education process. The findings of the research are deemed important in terms of revealing the advantages of distance education compared to face-to-face education from the perspectives of the instructors and students, and determining the fact that the workloads of the instructors in the distance education process decreased since the distance education process is more planned in terms of the design of the learning environment. A 70-hour training program was designed by Reisoğlu and Çebi (2020), which aimed to improve the digital competences of the pre-service teachers. This training program was applied to 24 pre-service teachers and at the end of the training program, the views of the pre-service teachers regarding their digital competencies were evaluated. The results of the study revealed that the training of the preservice teachers about how to use digital media in especially designing interactive learning and teaching environments is important in terms of understanding how they can better use digital skills to facilitate teaching.

When the literature was examined, it was found that the researches mostly focused on the students' virtual classroom experiences (Abdous, 2019; Abdous \& Yoshimura, 2010; Birişçi, 2013; Jin, 2005; Chen, Ou, Liu \& Liu, 2001; Ojo \& Olakuluhin, 2006), and that only a few study examined the teachers' teaching experience in virtual classroom environment (Cab1, 2018; Gülbahar \& Karataş, 2016; Kalelioğlu, Atan \& Çetin, 2016; Woodcock, Sisco \& Eady, 2015). On the other hand, few studies have focused on teachers' emotional responses to teaching online (Badia et al, 2017; Badia, et al., 2019; Regan et al., 2012). As a result, it was determined that "learning experiences" in virtual classroom environment were mostly analyzed; and despite the fact that some studies were found to examine the "teaching experience", no studies were found in which face-to-face and online synchronous teaching 
experience were discussed and evaluated together. In addition, to our knowledge, no studies compared the teaching experiences of pre-service teachers in terms of perceptions of teaching performance as a teacher and emotional responses for teaching in virtual classroom and for teaching in face to face. Another important contribution of this study to the literature is that it allows making an in-depth investigation of the topic by collecting both quantitative and qualitative data regarding the experiences of the pre-service teachers in both environments. This in-depth investigation may shed light on the understanding of the reasons of pre-service teachers' teaching environment preferences and their emotional responses to teaching, and it can also help to prepare pre-service teachers in order to effective use technology and pedagogy in both online and face to face teaching environments. Based on these discussions, the main purpose of the study was to examine the pre-service teachers' teaching experiences in virtual classroom and face-to-face teaching environment. Within the framework of this general purpose, it was aimed to find answers for the following questions:

1. What are the preferences of the pre-service teachers in terms of the teaching environments they have experienced?

2. What can be the reasons of the teaching environment preferences of the preservice teachers?

3. Is there a significant difference between the anxiety, motivation, performance and efficiency levels that the pre-service teachers perceive while performing the teaching role in virtual classroom and face-to-face teaching environment?

4. What can be the reasons of the pre-service teachers perceived anxiety, motivation, performance and efficiency levels?

\section{Method}

\section{Research Model}

In this study, which aimed to evaluate the teaching experiences of the pre-service teachers in virtual classroom and face-to-face teaching environment, complementarity mixed research method was used. In complementarity mixed method, which involves collecting, analyzing and combining quantitative and qualitative data within the research process (Teddlie $\&$ Tashakkori, 2009), each type of data analysis complements another (Brannen, 2005). This complementarity, which allows the measurement of both overlapping and diverging points, provides an in-depth 
investigation opportunity and a more enriched and detailed understanding (Greene, Caracelli \& Graham, 1989; Tondeur, Scherer, Siddiq \& Baran, 2020).

\section{Participants}

The participants of the research was composed of 40 Pre-Service Teachers (PST) studying in the $3^{\text {rd }}$ grade of the Department of Computer and Instructional Technologies in Aydin Adnan Menderes University and taking the course of Special Teaching Methods I and II in the 20182019 academic year. Of the pre-service teachers, 12 (30\%) were female, and 28 were $(70 \%)$ male. The mean age of the participants was 21.05 years (Ranging from 20 to 27 years). The interviews were conducted with all the pre-service teachers. The participants were a convenience sample formed by the pre-service teachers who pass the Special Teaching Methods I course and attend to the Special Teaching Methods II course. All participants had advance computer skills, but they had no previous teaching experiences in virtual classroom.

\section{Procedure of the Study}

The participants had two semesters of Special Teaching Methods course (Special Teaching Methods I at the $5^{\text {th }}$ term and Special Teaching Methods II at the $6^{\text {th }}$ term). This study took place at these two courses of the undergraduate program to which the participants were attending. Each participant taught face to face to their classmates (30 minutes) in the Special Teaching Methods I course. Upon completing the practicum, participants were required to evaluate their face-to-face teaching performance by filling out the teaching experience questionnaire I form. During the $6^{\text {th }}$ term, each participant taught virtually their classmates (20 minutes) via ZOOM platform in the Special Teaching Methods II course. Upon completing the virtual classroom practicum, participants were required to evaluate their virtual teaching performance by filling out the teaching experience questionnaire II form. At the end of $6^{\text {th }}$ term semi-structured interviews was conducted with participants in order to obtain detailed information regarding their teaching experiences in the two different teaching environments. The procedure of the study is given in Figure 1. 


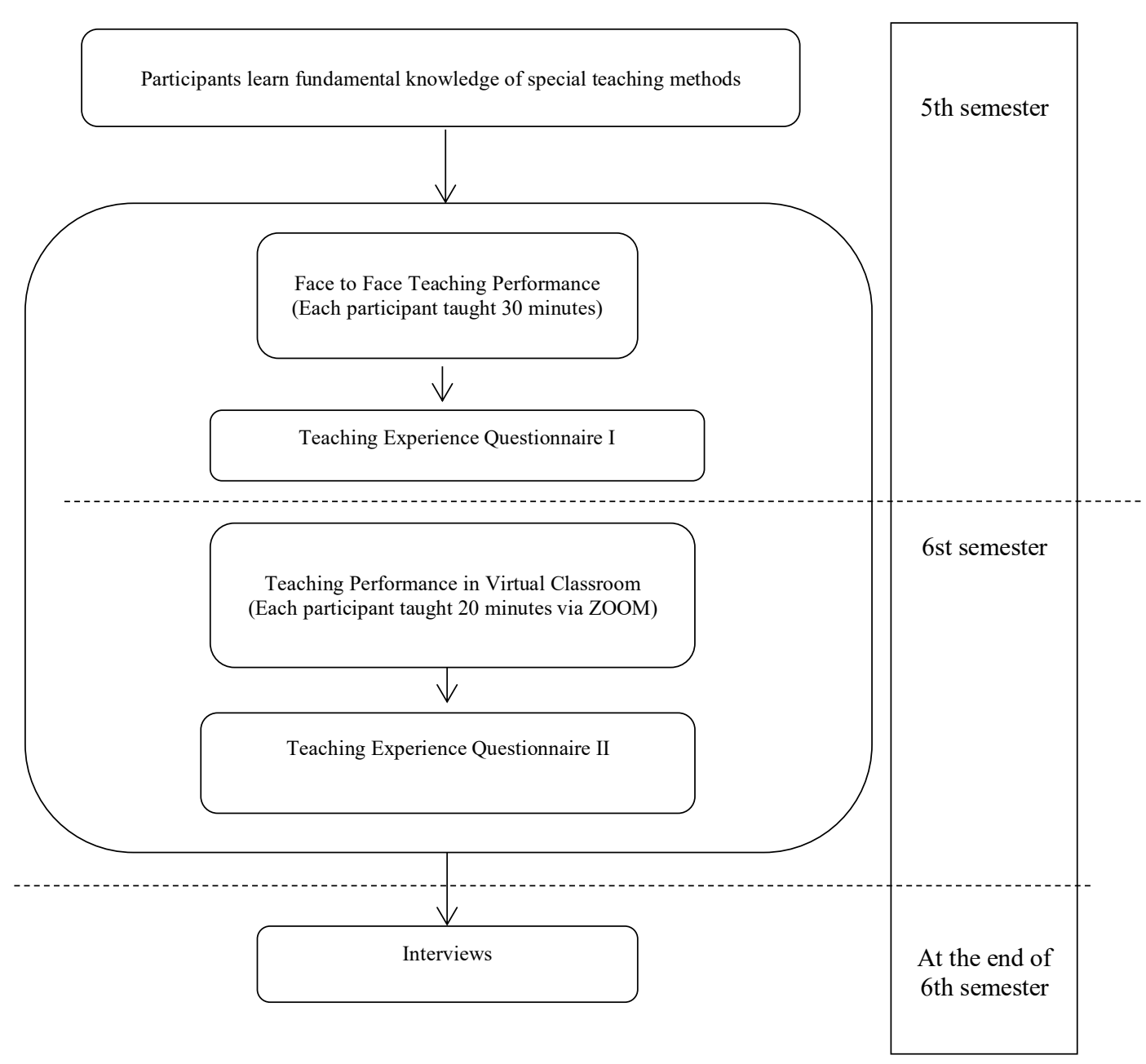

Figure 1. Procedure of the study

\section{Data Collection Tools}

Quantitative data were collected using "Teaching Experience Questionnaire I" and "Teaching Experience Questionnaire II", which were developed by the researchers. After the related literature was reviewed (Badia, et al., 2014; Chen, 2016; Trigwell, 2012), the draft questionnaire form was consulted to expert lecturers in order to ascertain the content validity. According to the views of the experts, necessary corrections were made. A pilot study was conducted with 28 pre-service teachers who studying in the $4^{\text {rd }}$ grade of the Department of Computer and Instructional Technologies program to test the intelligibility of the questionnaire forms. After inspecting the reaction in the pilot study, necessary modifications were made. The "Teaching Experience Questionnaire I" comprised six self-evaluation questions about participants' perceived performance and emotion levels while performing the teaching role in 
face-to-face teaching environment on a 10-point Likert scale from 1 (extremely low) to 10 (extremely high). “Teaching Experience Questionnaire II" included seven questions about participants' teaching environment preferences, their perceived performance and emotion levels while performing the teaching role in virtual classroom on a 10-point Likert scale from 1 (extremely low) to 10 (extremely high).

Qualitative data was collected through the semi-structured interview form, which was prepared by the researchers. While preparing the semi-structured interview form, the literature was reviewed, and the draft interview form was prepared considering the elements of the teaching performance and the features of teaching environments. The draft semi-structured interview form was consulted to experts and according to the views of the experts, necessary corrections were made. The semi-structured interview form consisted of five open-ended questions. These questions are: When you consider your personal experience as an instructor; 1) which teaching environment (Face to face or virtual classroom) was easier for you? Why? 2) What were the positive features of the teaching environments (Face to face and virtual classroom) that affect you teaching? 3) What were the negative features of the teaching environments (Face to face and virtual classroom) that affect your teaching? 4) Which competencies did you need more in order to increase the quality of the lesson (for face to face and for virtual classroom)? 5) Which teaching environment (face-to-face classroom / virtual classroom) would you prefer as a teacher? Why? All interviews were conducted face to face with each pre-service teacher individually.

\section{Data Analysis}

In the analysis of quantitative data, descriptive statistics regarding the pre-service teachers' environment preferences, perceived anxiety, motivation, performance and efficiency levels were used. The comparisons regarding the perceived anxiety, motivation, performance and efficiency levels of the pre-service teachers while performing the teaching role in virtual classroom and face-to-face teaching environment were analyzed by using Wilcoxon Signed Rank test. In the analysis of qualitative data, descriptive analyses were used. Interviews with pre-service teachers were transcribed and they were checked again to ensure their reliability. According to research questions, the codes associated with each other were grouped under specific themes. The descriptive validity of the research was provided by "researcher 
diversification". In this regard, the data of the research was analyzed by three different researchers by creating themes and sub-themes. The formula was described by Miles and Huberman (1994) used to determine the reliability of the study. According to Miles and Huberman (1994), when the consensus level among the reviewers was higher than $90 \%$, expected reliability was ensured. For this study the reliability was determined as $93 \%$.

Direct quotations were used to reflect the view of participants (Y 1ldırım \& Şimşek, 2011) in order to transferability was also made possible. In addition, credibility was ensured by the long-term involvement of the researchers with the participants and the research field.

\section{Ethical Issues}

All procedures performed in the study involving human participants were in accordance with the ethical standards of the Aydın Adnan menders University Ethics Committee and with the 1964 Helsinki declaration and its later amendments or comparable ethical standards. According to the TR DIZIN Journal Evaluation Criteria updated for 2020, the ethical committee permission is not obligatorily required in this study to be published in a journal indexed by TR DİZIN since the data were gathered before 2020.

\section{Findings}

\section{Teaching Environment Preferences}

When the preferences of the pre-service teachers regarding the teaching environments they experienced was examined, it was determined that $33(82.5 \%)$ of the pre-service teachers preferred face-to-face teaching environment, whereas 7 (17.5\%) of the pre-service teachers preferred virtual classroom environment (Table 1).

Table 1

Teaching Environment Preferences of the Pre-service Teacher.

\begin{tabular}{lll}
\hline Teaching Environment Preference & $\mathrm{f}$ & $\%$ \\
\hline Virtual Classroom & 7 & 17.5 \\
Face-to-face & 33 & 82.5 \\
Total & 40 & 100 \\
\hline
\end{tabular}




\section{Reasons of the Teaching Environment Preferences}

During the interviews conducted with the pre-service teachers, the reasons for the preferences of the pre-service teachers regarding the teaching environments were revealed. It could be said that the majority of the pre-service teachers preferred face-to-face teaching environment for such reasons as teacher-student interaction and eye contact; and that the pre-service teachers who preferred virtual classroom environment, though just a few in number, preferred this type of environment because of the fact that they felt more comfortable in this environment and thought that classroom management was easier. Some of the views of the pre-service teachers on this subject are presented below.

"If I had to make a choice, I would prefer face-to-face classroom... As I have to talk to the screen in virtual classroom application, I cannot understand how much interest my students show to the course and how much I can teach..." (PST1).

"If I had to choose as a teacher, I would prefer face-to-face classroom because I think that teacher-student interaction is more in face-to-face education and it disciplines students. When I say "discipline", I mean coming to class on time, obeying the classroom rules, being in the classroom during the lesson hours, etc. In addition to this, I also prefer face-to-face classroom so as to be able to observe the students' in-class behaviors as well as their behaviors outside the classroom." (PST3).

"I prefer virtual classroom because there is no classroom management stress in virtual classroom. Especially for the teachers who have difficulties to make their voice heard to the students at the backseat in face-to-face classroom, it is much easier to provide communication in virtual classroom." (PST9).

"The cost of virtual classroom is low. Ifeel more comfortable. Preparing the course material is easier. It makes me feel like I am the boss in my job." (PST30).

"In face-to-face teaching environment, student-teacher interaction, sharing information and emotions is better. Technical problems are limited." (PST32).

"If I had to choose as a teacher, I would prefer face-to-face classroom. The reason for this is certainly the fact that communication is stronger." (PST39). 


\section{Perceived Anxiety, Motivation, Performance and Efficiency Levels}

When perceived anxiety, motivation, performance and efficiency scores of the pre-service teachers while performing the teaching role in virtual classroom and face-to-face teaching environment were analyzed (Table 2), it was found that the anxiety level they perceived in face-to-face teaching environment $(\bar{X}=5.55)$ was lower than the anxiety level they perceived in virtual classroom environment $(\bar{X}=6.20)$. It was also determined that the mean scores of motivation $(\bar{X}=7.72)$, performance $\bar{X}=7.65)$ and efficiency $(\bar{x}=7.85)$ they perceived in face-to-face teaching environment was higher than the mean scores of motivation $(\bar{X}=5.90)$, performance $(\bar{X}=6.02)$ and efficiency $(\bar{X}=5.07)$ in virtual classroom environment.

Table 2

Perceived Anxiety, Motivation, Performance and Efficiency Scores of the Pre-service Teachers While Performing the Teaching Role in Virtual Classroom And Face-to-Face Teaching Environment

\begin{tabular}{lllll}
\hline & Environment & $\mathrm{N}$ & $\overline{\mathbf{X}}$ & $\mathrm{SD}$ \\
\hline Perceived & Virtual Classroom & 40 & 6.20 & 2.27 \\
Anxiety & Face-to-face & & 5.55 & 2.76 \\
\hline Perceived & Virtual Classroom & 40 & 5.90 & 1.98 \\
Motivation & Face-to-face & & 7.72 & 1.55 \\
\hline Perceived & Virtual Classroom & 40 & 6.02 & 2.08 \\
Performance & Face-to-face & & 7.65 & 1.85 \\
\hline Perceived & Virtual Classroom & 40 & 5.07 & 2.21 \\
Efficiency & Face-to-face & & 7.85 & 1.85 \\
\hline
\end{tabular}

The results of Wilcoxon Signed Rank test performed in order to reveal whether there was a statistically significant difference among the perceived anxiety, motivation, performance and efficiency scores of the pre-service teachers while performing the teaching role in these two different teaching environments are presented in Table 3. 
Comparison of Pre-Service Teachers' Teaching Experiences in Virtual Classroom and Face-to-Face Teaching Environment

Table 3

Comparisons Regarding the Perceived Anxiety, Motivation, Performance and Efficiency Levels of the Pre-service Teachers While Performing the Teaching Role in Virtual Classroom And Face-to-Face Teaching Environment.

\begin{tabular}{|c|c|c|c|c|c|c|}
\hline & $\begin{array}{l}\text { (Face-to-face) } \\
\text { (Virtual Classroom ) }\end{array}$ & $-\mathrm{N}$ & $\begin{array}{l}\text { Mean } \\
\text { Rank }\end{array}$ & Total Rank & $\mathrm{z}$ & $\mathrm{p}$ \\
\hline \multirow{3}{*}{ 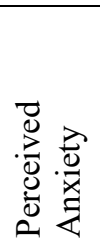 } & Negative Ranks & 21 & 21.33 & 448 & -1.46 & .143 \\
\hline & Positive Ranks & 16 & 15.94 & 255 & & \\
\hline & Equal & 2 & & & & \\
\hline \multirow{3}{*}{ 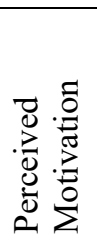 } & Negative Ranks & 8 & 14.38 & 115 & -3.53 & .000 \\
\hline & Positive Ranks & 30 & 20.87 & 626 & & \\
\hline & Equal & 2 & & & & \\
\hline \multirow{3}{*}{ 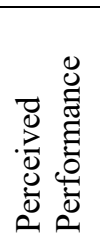 } & Negative Ranks & 10 & 11.90 & 119 & -3.73 & .000 \\
\hline & Positive Ranks & 27 & 21.63 & 584 & & \\
\hline & Equal & 3 & & & & \\
\hline \multirow{3}{*}{ 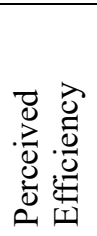 } & Negative Ranks & 8 & 7.75 & 62 & -4.38 & .000 \\
\hline & Positive Ranks & 29 & 22.10 & 641 & & \\
\hline & Equal & 3 & & & & \\
\hline
\end{tabular}

As a result of Wilcoxon Signed Rank test performed in order to reveal whether there was a statistically significant difference among the perceived anxiety, motivation, performance and efficiency scores of the pre-service teachers while performing the teaching role in virtual classroom and face-to-face teaching environment, it was determined that there was not a significant difference in terms of perceived anxiety $(\mathrm{z}=-1.46, \mathrm{p}>.05)$; whereas there was a statistically significant difference in terms of perceived motivation $(\mathrm{z}=-3.53, \mathrm{p}<.00)$ with a large effect size $(r=-0.55)$, perceived performance $(\mathrm{z}=-3.73, \mathrm{p}<.00)$ with a large effect size $(\mathrm{r}=-$ $0.59)$, and perceived efficiency $(\mathrm{z}=-4.38, \mathrm{p}<.00)$ with a large effect size $(\mathrm{r}=-0.69)$ on behalf of the experience in face-to-face teaching environment (positive ranks) (Table 3). 


\section{Reasons of the Pre-Service Teachers Perceived Anxiety, Motivation, Performance and Efficiency Levels}

During the interviews conducted, the reasons for the anxiety perceived by the pre-service teachers regarding both virtual classroom and face-to-face teaching environments were revealed. It could be said that the pre-service teachers had the anxiety of teaching in front of the class, not being able to use their body language effectively and forget what to tell in faceto-face teaching environment; whereas they had the anxiety of facing technical problems in s virtual classroom environment. Some of the views of the pre-service teachers on this subject are presented below.

“...Virtual classroom has been easier for me. As a result, I made a plan in my head and I was not worried about the lectures as I would not be in a scene environment." (PST13).

"In synchronous classroom application, the technical problems experienced in the computer and the materials I used panicked me and I could not express myself clearly." (PST14).

"Virtual classroom environment is easier due to the convenience of being alone and as the materials are with me because of the fact that I may be concerned about forgetting the things I will teach." (PST19).

"In face-to-face environment, the anxiety level is high, and thus, it is required to work harder in order to be able to use body language effectively." (PST22).

In the interviews conducted, the pre-service teachers expressed that their motivation was low in virtual classroom environment due to such reasons as talking to the camera and being unable to ensure student participation; and that it was also low in face-to-face teaching environment due to such reasons as being excited and not being able to use body language effectively. Some of the views of the pre-service teachers on this subject are presented below.

"Talking to the camera in synchronous virtual classroom gave me a strange feeling. Talking in front of the students and getting feedback was important for a more enjoyable and fluent lesson." (PST22).

"In virtual classroom, I was tired after a while since I could not provide student participation just because I was teaching on my own, and my voice was thrilling, which was a very tedious situation for me." (PST23). 
Comparison of Pre-Service Teachers' Teaching Experiences in Virtual Classroom and Face-to-Face Teaching Environment

"The feeling that I was talking to the camera in synchronous virtual classroom is really boring." (PST38).

"Since I was anxious when I first appeared on stage in face-to-face classroom application, I used the same body language from beginning till the end of the lesson and I could not be very energetic." (PST13).

In the interviews conducted, the pre-service teachers stated that their performance was low in virtual classroom environment due to such reasons as not being able to make eye contact, less interaction and not being able to take individual differences into consideration; and that it was also low in face-to-face teaching environment due to such reasons as being excited and not being able to provide the control of the classroom. Some of the views of the pre-service teachers on this subject are presented below.

"I could not take into account the individual differences of the students in virtual classroom." (PST7).

"Since I made too much effort in order to provide classroom control in face-to-face education, I sometimes went off the subject and spent a certain amount of time for returning back to the subject. During this time, I experienced difficulties in teaching the whole subject and could not get some of the activities done." (PST23).

"Since I was on my own in synchronous virtual classroom, there was not much interaction and I felt like I was shooting videos rather than teaching the lesson. I was overwhelmed by my excitement from time to time in face-to-face classroom and this affected the way I taught quite a lot." (PST31).

"Since I was in front of the computer in synchronous classroom, I could not perform enough teaching because I was just like talking to myself." (PST36).

In the interviews conducted, the pre-service teachers emphasized that the technical problems experienced and not being able to make eye contact in virtual classroom environment decreased the efficiency of the lesson; whereas having the opportunity to interact and make eye contact with the students in face-to-face teaching environment increased the efficiency of the lesson. Below are some of the opinions of pre-service teachers on this subject.

"While I was teaching synchronously in virtual classroom, some of my students could not benefit from the course effectively because they had problems with the speed or quality of their internet connection. Although this situation seemed as a technical problem, it created a remarkable problem in achieving the goal of the course." (PST3). 
"The interaction with the students in face-to-face classroom makes the teaching livelier and easier to understand. I also think it also makes the teaching convenient for the teacher." (PST10).

"In face-to-face classroom environment, classroom interaction was extremely high. Therefore, I think the lesson was more efficient. As I had the opportunity to make eye contact with all the students, I could make everyone participate actively. It was easier to motivate the students in terms of participating them in the lesson." (PST19).

\section{Discussion and Conclusion}

In this study, it was aimed to evaluate the pre-service teachers' teaching experiences in virtual classroom and face-to-face teaching environment. In accordance with this purpose, the results regarding the pre-service teachers' teaching environment preferences, the anxiety, motivation, performance and efficiency levels they perceived while performing the teaching role in virtual classroom and face-to-face teaching environment, and the reasons for the emotional responses were obtained. As a result of the research, it was determined that the majority of the pre-service teachers preferred face-to-face teaching environment for such reasons as teacher-student interaction and eye contact. This finding coincides with the findings of the researches that revealed such negative views of the students regarding virtual classroom environments as the lack of face-to-face communication and low student-teacher interaction (Berge, 2002; Birişçi, 2013; Jin, 2005; Chen, et al., 2001; Ojo \& Olakuluhin, 2006). Within the framework of this study, it was noteworthy that the pre-service teachers preferred face-to-face environment, not as a student but because of the same negative views as a teacher in virtual classroom environment.

While there was not a significant difference in terms of the anxiety levels perceived by the preservice teachers during performing the teaching role in virtual classroom and face-to-face teaching environment, it was determined that there was a significant difference in terms of the perceived motivation, performance and efficiency on behalf of face-to-face teaching experience. The fact that the anxiety of lecturing in front of the classroom, not being able to using body language effectively and forgetting what to teach in face-to-face teaching environment expressed by the pre-service teacher is balanced with the anxiety of experiencing technical problems in virtual classroom environment can be considered as the reason why there 
was not a significant difference in terms of anxiety level for both of the teaching environments. Interestingly, not being on the stage in virtual classroom environment reduces the anxiety level of the pre-service teachers, whereas perceived motivation, perceived performance and perceived efficiency levels regarding virtual classroom experience decreases due to the fact that not being on the stage also yields such consequences as being unable to talk to the camera and being unable to make eye contact. This finding coincides with the findings in the literature revealing that technical problems in distance education negatively affect student motivation (Birişçi, 2013; Gilkes, 2020; Kalelioğlu et al., 2016; Ojo \& Olakuluhin, 2006) and teachers' emotional response toward online teaching (Badia et al., 2019; Naylor \& Nyanjom, 2020;. The decrease in student motivation can be considered as a factor that reduces perceived performance and perceived efficiency by creating the perception that the teacher is not able to provide student participation sufficiently and that the lesson is not productive. For this reason, as also stated by Y1ldı (2011), in order to minimize the technical problems in virtual classroom applications, it is extremely important to eliminate the technical infrastructure deficiencies at the institutional level and provide continuous internet connection. In the relevant literature, the positive impact of institutional support on both preservice and in-service teachers' emotions to teaching online is also recognized (Naylor \& Nyanjom, 2020; Nelson, Voithofer \& Cheng, 2019). A recent study conducted by Naylor \& Nyanjom (2020) reported a significant relationship between teachers' emotional responses type to teaching online and the perceived amount of institutional support.

The results of this study highlight the factors influencing pre-service teachers' teaching environment preferences and their emotional responses toward teaching. These factors are mostly related to the nature of virtual classroom where somewhat limit nonverbal interaction. Actually positive interaction between teachers and students is an important source of positive emotions for teacher (Chen, 2016). In this context, training programs for pre-service teachers aimed at providing knowledge and skills on interaction opportunities in virtual classrooms should be conduct. It was also revealed in this study that the pre-service teachers emphasized "interaction" most. The importance of interaction in online teaching is frequently emphasized in the literature (Moore, 1993; Swan, 2002; Wilson \& Stacey, 2004). For this reason, it is important to organize the course activities carried out in virtual classroom environment in such a way that they enable the students to be more active (Kalelioğlu et al., 2016; Sae-Khow, 2014). At this point, it is possible to benefit from the features of current virtual classroom software 
that is similar to the one present in real class environment and from the opportunities that will increase interaction (İzmirli \& Akyüz, 2017). As well as the availability of these opportunities, the fact that these opportunities are indigenized and used by the teacher is of great importance. According to Song, Kim \& Luo (2016), teachers should know different characteristics of online and face to face teaching and being skilled using tailored strategies for increase interaction. Therefore, pre-service teachers should be given the opportunity to experiences of teaching online where they are able to use these software and interaction opportunities.

In conclusion, it was determined in this study that among the reasons why the majority of the pre-service teachers preferred face-to-face teaching environment were such reasons as the anxiety of experiencing technical problems, not being able to use the interaction opportunities offered by virtual classroom environments and not being able to provide student participation. Based on this finding, it is necessary to teach pre-service teachers the technical specifications of virtual classroom environments and the interaction opportunities they offer, as well as training them in terms of the competencies to teach in these environments. In such a time period when digital transformation is experienced so rapidly, it is extremely significant for pre-service teachers to graduate by obtaining the necessary knowledge, skills and experience for virtual classroom environments as well as for face-to-face education environments.

\section{Limitations and future research directions}

Although the present findings add to our understanding of the reasons of pre-service teachers' teaching environment preferences and their emotional responses for both teaching in virtual classroom and teaching in face to face, there are several limitations worth noting. First, the results of the study have a limited generalizability. Besides, in this study, the collected data were limited to self-report data in the questionnaires and interviews. Future research may use a scale for collecting quantitative data and integrate observations and peer evaluations of preservice teachers while they are performing the teaching role. Second, in this study, previous virtual classroom experiences of the pre-service teachers were not considered as a variable. However, some of the findings obtained may be correlated with the fact that the pre-service teachers who participated in the study experienced teaching in virtual classroom for the first time and that they had just a little experience in this subject. It is deemed significant to develop self-efficacy beliefs by pre-service teachers regarding the fact that they can teach the class effectively in virtual classroom environment as well as in face-to-face teaching environment 
(Cakiroglu, Cakiroglu \& Boone, 2005; Gorrell \& Dharmadasa, 1994; Lambe, 2007; Woodcock et al., 2015). For this reason, there is a requirement for the applications that will increase virtual classroom experiences of pre-service teachers and for the studies examining the effects of this experience.

\section{Statements of Ethics and Conflict of Interest}

"I, as the Corresponding Author, declare and undertake that in the study titled as "The Comparison of Pre-Service Teachers' Teaching Experiences in Virtual Classroom and FaceTo-Face Teaching Environment", scientific, ethical and citation rules were followed; Turkish Online Journal of Qualitative Inquiry Journal Editorial Board has no responsibility for all ethical violations to be encountered, that all responsibility belongs to the author/s and that this study has not been sent to any other academic publication platform for evaluation. "

\section{References}

Abdous, M. (2019). Influence of satisfaction and preparedness on online students' feelings of Anxiety. The Internet and Higher Education, 41, 34-44.

Abdous, M., \& Yoshimura, M. (2010). Learner outcomes and satisfaction: A comparison of live video-streamed instruction, satellite broadcast instruction, and face-to-face instruction. Computers \& Education, 55(2), 733-741.

Agyei, D. D., \& Voogt, J. M. (2011). Exploring the potential of the will, skill, and tool model in Ghana: Predicting prospective and practicing teachers' use of technology. Computers \& Education, 56 (1), 91-100.

Anderson, D. L., Standerford, N. S., \& Imdieke, S. (2010). A self-study on building community in the online classroom. Networks, 12(2), 1-10.

Badia, A., Garcia, C., \& Meneses, J. (2017). Approaches to teaching online: Exploring factors influencing teachers in a fully online university. British Journal of Educational Technology, 48, 1193-1207. 
Badia, A., Garcia, C., \& Meneses, J. (2019) Emotions in response to teaching online: Exploring the factors influencing teachers in a fully online university, Innovations in Education and Teaching International, 56:4, 446-457

Badia, A., Meneses, J., \& Monereo, C. (2014). Affective dimension of university professors about their teaching: An exploration through the semantic differential technique. Universitas Psychologica, 13, 161-173.

Baker, J. D. (2004). An investigation of relationships among instructor immediacy and affective and cognitive learning in the online classroom. The Internet and Higher Education, 7(1), 1-13.

Bandura, A. (1977). Self-efficacy: Toward a unifying theory of behavioral change. Psychological Review, 84(2), 191-215.

Bennett, L. (2014). Putting in more: Emotional work in adopting online tools in teaching and learning practices. Teaching in Higher Education, 19(8), 919-930.

Berge, Z. (2002). Active, interactive, and reflective elearning, Quarterly Review of Distance Education, 3(2), 181-190.

Birişçi, S. (2013). Video Konferans Tabanlı Uzaktan Eğitime İlişkin Öğrenci Tutumları ve Görüşleri. Journal of Instructional Technologies \& Teacher Education, 1(2), 24-40.

Brannen, J. (2005). Mixing Methods: The Entry ff Qualitative and Quantitative Approaches into The Research Process. The International Journal of Social Research Methodology, 8(3): 173-185.

Cab1, E. (2018). Teaching Computer Literacy via Distance Education: Experiences of the Instructors. Başkent University Journal of Education, 5(1), 61-68.

Cakiroglu, J., Cakiroglu, E., \& Boone, W. (2005). Pre-service teacher self-efficacy beliefs regarding science teaching: A comparison of pre-service teachers in Turkey and the USA. Science Educator, 14, 31-40.

Chen, G. D., Ou, K. L., Liu, C. C., \& Liu, B. J. (2001). Intervention and strategy analysis for web group-learning, Journal of Computer Assisted Learning, 17, 58-71.

Chen, J. (2016). Understanding teacher emotions: the development of a teacher emotion inventory. Teaching and Teacher Education, 55, 68-77.

Chen, J. (2019). Exploring the impact of teacher emotions on their approaches to teaching: A structural equation modelling approach. British Journal of Educational Psychology, $89(1), 57-74$.

Compton, L. K. L., Davis, N. E., \& Mackey, J. (2009). Field experience in virtual schools - to be there virtually. Journal of Technology and Teacher Education, 17(4), 459-477. 
Downing, J. J. \& Dyment, j. E. (2013). Teacher Educators' Readiness, Preparation, and Perceptions of Preparing Preservice Teachers in a Fully Online Environment: An Exploratory Study, The Teacher Educator, 48:2, 96-109.

Ertmer, P. A. \& Ottenbreit-Leftwich, A. T. (2010). Teacher technology change: how knowledge, beliefs, and culture intersect. Journal of Research on Technology in Education, 42, 255-284.

Gilkes, A., L. (2020). Teachers' Knowledge and Self-Efficacy Beliefs as Factors Affecting Technology Integration Practices. Walden Dissertations and Doctoral Studies. 9365. Retrieved November 30, 2020 from https://scholarworks.waldenu.edu/dissertations/ 9365.

Gorrell, J., \& Dharmadasa, K. (1994). Perceived self-efficacy of pre-service and in-service Sri Lankan teachers. International Education, 24, 23-36.

Greene, J. C., Caracelli, V. J., \& Graham, W. F. (1989). Toward a conceptual framework for mixed-method evaluation designs. Educational Evaluation and Policy Analysis, 11(3), 255-274.

Gudmundsdottir, G. B., \& Hatlevik, O. E. (2018). Newly qualified teachers' Professional digital competence: implications for teacher education, European Journal of Teacher Education, 41(2), 214-231.

Gülbahar, Y. \& Karataş, E. (2016). Learning Distance Teaching via Distance Learning: "EInstructor Certificate Program”. Kastamonu Eğitim Dergisi, 24(4), 1867-1880.

He, Y. (2014). Universal Design for Learning in an Online Teacher Education Course: Enhancing Learners' Confidence to Teach Online. MERLOT Journal of Online Learning and Teaching, 10 (2): 283-297.

İzmirli, S., Akyüz, H. İ.. (2017). Eş Zamanlı Sanal Sınıf Yazılımlarının incelenmesi. Eğitimde Kuram ve Uygulama, 13(4), 788-810.

Jin, S. H. (2005). Analyzing student-student and student-instructor interaction through multiple communication tools in web-based learning, International Journal of Instructional Media, 32, 1, 59-67.

Kairu, C. (2020). The Role of the Instructor in Asynchronous Learning: Students' Views. In E. Langran (Ed.), Proceedings of SITE Interactive 2020 Online Conference (pp. 63-72). Online: Association for the Advancement of Computing in Education (AACE). Retrieved November 29, 2020 from https://www.learntechlib.org/p/218121. 
Kalelioğlu, F., Atan, A. \& Çetin, Ç. (2016). Sanal sınıf eğitmen ve öğrenen deneyimleri. Mersin Üniversitesi Ĕ̆itim Fakültesi Dergisi, 12(2), 555-568.

Kennedy, K., \& Archambault, L. (2012). Offering preservice teachers field experiences in K12 online learning: A national survey of teacher education programs. Journal of Teacher Education, 63(3), 185-200.

Lambe, J. (2007). Student teachers, special education need and inclusion education: Reviewing the potential for problem-based, e-learning pedagogy to support practice. Journal of Education for Teaching: International Research and Pedagogy, 33, 359-377.

Miles, M. B., Huberman, A. M. (1994). Qualitative data analysis: An expanded sourcebook. Sage.

Moore, M. G. (1993). Theory of transactional distance. In D. Keegan (Ed.), Theoretical principles of distance education (pp. 22-38). New York: Routledge.

Naylor, D. \& Nyanjom, J. (2020). Educators' emotions involved in the transition to online teaching in higher education. Higher Education Research \& Development, DOI: 10.1080/07294360.2020.1811645.

Nelson, M. J., Voithofer, R., \& Cheng, S. L. (2019). Mediating factors that influence the technology integration practices of teacher educators. Computers \& Education, 128, 330-344. doi:10.1016/j.compedu.2018.09.023

Ojo, D.O., \& Olakuluhin, F.K. (2006). Attitudes and perceptions of students to open and distance learning in Nigeria, International Review of Research in Open and Distance Learning, 7(1), 1-10.

Reisoğlu, İ. \& Çebi, A. (2020). How can the digital competences of pre-service teachers Be developed? Examining a case study through the lens of DigComp and DigCompEdu, Computers \& Education (2020), doi: https://doi.org/10.1016/j.compedu.2020.103940.

Regan, K., Evmenova, A., Baker, P., Jerome, M. K., Spencer, V., Lawson, H., \& Werner, T. (2012). Experiences of instructors in online learning environments: Identifying and regulating emotions. The Internet and Higher Education, 15(3), 204-212.

Sae-Khow, J. (2014). Developing of Indicators of an E-Learning Benchmarking Model for Higher Education Institutions. TOJET: The Turkish Online Journal of Educational Technology, 13(2), 35-43.

Shea, P., Li, C. S., \& Pickett, A. (2006). A study of teaching presence and student sense of learning community in fully online and web-enhanced college courses. The Internet and Higher Education, 9(3), 175-190. 
Song, H, Kim, J \& Park, N . 2019. I know my professor: Teacher self-disclosure in online education and a mediating role of social presence. International Journal of HumanComputer Interaction, 35(6):448-455.

Sprague, D., Kopfman, K., \& Dorsey, S.L. (1998). Faculty development in the integration of technology in teacher education courses. Journal of Computing in Teacher Education, 14(2), 24-28.

Swan, K. (2002). Building learning communities in online courses: the importance of interaction. Education, Communication \& Information, 2(1), 23-49.

Teddlie, C. \& Tashakkori, A. (2009). Foundations of mixed methods research: Integrating quantitative and qualitative approaches in the social and behavioral sciences. Thousand Oaks, CA: Sage.

Telli-Yamamoto, G. \& Altun, D. (2020). Coronavirüs ve Çevrimiçi (Online) Eğitimin Önlenemeyen Yükselişi. Journal of University Research, 3(1), 25-34.

Tondeur, J., Scherer, R., Siddiq, F., \& Baran, E. (2020). Enhancing preservice teachers' technological pedagogical content knowledge (TPACK): A mixed method study. Educational Technology Research \& Development, 68(1), 319-343.

Trigwell, K. (2012). Relations between teachers' emotions in teaching and their approaches to teaching in higher education. Instructional Science, 40, 607-621.

Vygotsky, L. S. (1978). Mind in society: The development of higher psychological processes. Cambridge, MA: Harvard University Press.

Wilson, G. \& Stacey, E. (2004). Online interaction impacts on learning: Teaching the teachers to teach online, Australasian Journal of Educational Technology, 20(1), 33-48.

Woodcock, S., Sisco, A. \& Eady, M. (2015). The learning experience: Training teachers using online synchronous environments. Journal of Educational Research and Practice, 5(1), 21-34.

Yang, J., Zhu, F., Guo, P. \& Pi, Z. (2020). Instructors' gestures enhance their teaching experience and performance while recording video lectures. J. Comput. Assist. Learn. 36(2): 189-198.

Yıldırım, A. ve Şimşek, H. (2016). Sosyal bilimlerde nitel araştırma yöntemleri. (10. Baskı). Ankara: Seçkin Yayıncılık.

Yıldız, E. (2011). Web-tabanlı senkron derslerin öğretmen adaylarının uzaktan eğitime karşı tutumlarl ve senkron teknolojileri kabulleri üzerine etkisi (Yayınlanmamış yüksek lisans tezi), Balıkesir Üniversitesi, Balıkesir. 
Yılmazsoy, B., Özdinç, F. \& Kahraman, M. (2018). Sanal Sınıf Ortamındaki Sınıf Yönetimine Yönelik Öğrenci Görüşlerinin İncelenmesi. Trakya Journal of Education $8(3), 513-525$.

Yordam, M. F., \& Bülbül, T. (2018). Öğretmenlerin Özyeterlilik Algılarının Çevrimiçi Öğrenmeye Yönelik Hazırbulunuşlulukları ile İlişkisi. Trakya University Journal of Social Science, 20(1), 447-470. 